\title{
Studying Marriage Migration to Europe from Below: Informal Practices of Government, Border Struggles and Multiple Entanglements
}

by Stephan Scheel ${ }^{1}$ and Miriam Gutekunst ${ }^{2}$

This is the author accepted pre-proof version of an article published by Taylor \& Francis on

25 Jan 2019 in: Gender, Place and Culture (2019) 26:6, 847-867.

The final version is available online at: https://doi.org/10.1080/0966369X.2018.1489375

Abstract: The growing importance of marriage as a migration strategy has been accompanied by a problematisation and securitization of marriages between binational couples in media and policy discourse. Moreover, marriage migration has received increased scholarly attention. In this article we propose an analytical framework for the study of marriage migration and its government that permits to transcend three biases and related blind spots that we identify in the existing literature. While this literature offers rich insights into marriage migration and states' ever more laboured attempts to control and regulate it, this literature is, nevertheless, characterised by an implementation gap bias, a control bias and, finally, a destination country bias. To address these biases we propose an analytical framework that is inspired by the autonomy of migration approach. We propose to ethnographically study binational couples' encounters with marriage migration related authorities in countries of destination and citizenship with a particular focus on binational couples' struggles for visas, resident permits and a right to family life. Illustrated through ethnographic research, we show that this methodology permits to highlight three aspects of marriage migration that have not been sufficiently considered so far. These include the securitization of marriage migration 'from below' through informal practices of government on the 'street-level', binational couples' inherently political border struggles and their capacity to negotiate restrictive legislations and bureaucratic hurdles and, finally, what we call the multiple entanglements of binational couples in the border and citizenship regimes of two or more nation-state orders.

Keywords: autonomy of migration, destination country bias, marriage migration, policy implementation, securitization, visa policy

\footnotetext{
${ }^{1}$ Corresponding author. University of Duisburg-Essen, Institute of Sociology: stephan.scheel@uni-due.de

${ }^{2}$ Ludwig-Maximilian-University Munich, Institute of Cultural Studies and European Ethnography.
} 
In the past two decades marriage migration has become one of the main legal modes of entry to Europe In the European Union (EU) this has been accompanied by the problematisation of marriages between EU and non-EU citizens through discourses on 'fake', 'sham' and 'grey' marriages that allegedly only serve to secure a residence title (D'Aoust 2013, 2017). These often racialized discourses have justified the introduction of restrictive regulations and administrative policing of marriages between EU and non-EU citizens (Eggebø 2013, Muller Myrdahl 2010, Wray 2006, Bonjour and de Hart 2013). Due to these developments marriage migration features prominently on the research agenda of contemporary border and migration studies. ${ }^{3}$ In this article we want to contribute to this growing body of literature by proposing an analytical framework that permits to better account for some aspects of marriage migration and its governance that havenot been sufficiently considered so far.

Inspired by the autonomy of migration approach (AoM), we therefore outline an analytical framework that studies binational couples' 'embodied encounters' (Scheel 2013b) with street-level bureaucrats in migration related administrations with a particular focus on their 'border struggles' (Mezzadra and Neilson 2013). Such multi-sited, ethnographic research (Marcus 1995) better accounts for three central aspects of marriage migration and its 'management': First, how intersecting discriminations along lines of class, race, gender, age, sexual orientation, nationality etc. play themselves out in informal practices of government on the street-level of policy implementation, secondly, binational couples' capacity to negotiate restrictive legal restrictions and administrative hurdles, and thirdly, the multiple entanglements of binational couples, who are compelled to struggle within and against the legislative frameworks and bureaucratic jungles of two or more nation-state orders.

In this way this article contributes to the existing literature, which, while offering rich insights on marriage migration and its government, is characterised by three biases. We understand these biases as tendencies in the existing literature on marriage migration as a whole and acknowledge that there exist exceptions in regards to any of the three biases identified by us.

\footnotetext{
${ }^{3}$ In this article we use 'marriage migration' as an umbrella term for all marriages and related migration processes that feature binational couples in which at least one person does not hold formal citizenship of the desired country of residence (Williams 2012). Since we are particularly interested in the actual processes of marriage and migration and the bureaucratic procedures and border struggles these imply for binational couples we prefer 'marriage migration' over the term 'transnational marriage', which guides the research interest more towards transnational ties, communities and networks (Charsley 2012).
} 
The first of these tendencies is of a methodological nature. Due to their reliance on discourse and policy analysis, many studies do not sufficiently capture the at times significant divergence between official policy and legal frameworks and their actual implementation on the 'street-level' (Lipsky 1980). We call this tendency ‘implementation gap bias’. ${ }^{4}$ The second tendency concerns the mostly one-dimensional focus on ever more restrictive legal frameworks and administrative practices. The practices, tactics and allies that binational couples mobilise to negotiate these play, in most cases, only a subordinate role (for exceptions see: Carver 2013, Cole 2014, Leinonen and Pellander 2014, Wagner 2015). The result is a 'control bias' that overrates the capacity of authorities to regulate marriage migration. Finally, the existing literature on marriage migration tends to reflect the 'destination country bias' (Czaika and Haas 2014) that continues to shape migration research in general. Most studies concentrate their analysis on regulations in destination countries. The bureaucratic hurdles binational couples have to navigate in countries of citizenship of the non-EU spouse are in contrast, if at all, only treated in footnotes (see though: Fernandez 2013, Alexander 2013)

After elaborating on these biases in the first section, we specify the analytical framework we propose to address them. The remaining three sections illustrate how our framework permits to highlight aspects of marriage migration and its governance that tend to be underresearched due to the three biases identified by us. The second section demonstrates that it is important to account for informal practices of government on the street-level by showing how consular staff securitize marriage migration 'from below'. .It also highlights that a focus on binational couples' encounters with officials permits to capture how intersecting discriminations along lines of class, race, gender, age, nationality etc. are enacted by bordering practices mobilised for the government of marriage migration. . The third section illustrates that binational couples' capacity to contest restrictive regulations and administrative practices constitutes a nonnegligible factor in the study of marriage migration. Drawing on the example of GermanMoroccan couples, the fourth section demonstrates that binational couples have to navigate the paper requirements and administrative obstacle courses of two or more nation-states, highlighting the importance to account for these multiple entanglements.

One crucial benefit of our analytical framework is that it permits to tease out how gender and other intersecting categorisations are constantly enacted in bureaucratic procedures and practices involved in the regulation of marriage migration . In the existing literature on marriage migration “"gendered” has often meant “female”' (Wray 2015: 426), thus reducing a gender-

\footnotetext{
${ }^{4}$ There exists numerous exceptions in regards to the implementation gap bias that we discuss in detail in the next two sections.
} 
sensitive analysis to a focus on women and their agency (e.g. Constable 2004, Piper and Roces 2003). We suggest, in contrast, to study how bordering practices constitute gender differences in the first place, and hence, how the (re)production of gender, 'doing gender ${ }^{5}$, is intertwined with the (re)production of borders, 'doing borders' (Gutekunst 2016). Hence, we propose to ethnographically research how (national) borders and gender (differences) are enacted in binational couples' encounters with officials on the street-level of policy implementation (Scheel 2013b).

Finally, a note on the fieldwork informing this intervention is needed. This paper draws on extensive ethnographic research that has been conducted in and around consulates of Schengen member states in two North African countries between 2012 and 2014 . We conducted this research independently from one another in two separate $\mathrm{PhD}$ projects and only developed the argument together afterwards. In her $\mathrm{PhD}$ Miriam worked on the meaning of marriage as a migration strategy and an instrument of control within the European border regime. Besides conducting interviews and participant observations in institutions related to the European border regime, Miriam accompanied 15 couples for up to one and a half years during the entire marriage migration procedure. Stephan's $\mathrm{PhD}$ project focused, in turn, on how migrants appropriate mobility to Europe within biometric border regimes. To this end Stephan studied the encounters between migrants and the Visa Information System (VIS), one of the world's largest biometric databases, at consulates in North Africa, an international airport and migration administrations in Europe. Of particular relevance for this article are the observations Stephan conducted in an anonymised consulate in North Africa (hereafter consulate Z). These were complemented by more than 40 interviews with consular staff, aspiring migrants and visa applicants. Both Miriam and Stephan experienced difficulties with getting access to institutions and gaining trust of research participants, partly because of their positionality as white European researchers. ${ }^{6}$ While the second section draws primarily on Stephan's research in consulate Z,

\footnotetext{
5 We understand 'doing gender' as an 'ongoing activity [that is] embedded in everyday interaction' (West/Zimmerman 1987: 130). This understanding of gender as an effect of performative discourses and practices is of course inspired by Judith Butler's work (1993).

${ }^{6}$ Doing ethnographic research as a white European in North Africa implicates certain advantages, challenges and conflicts. On the one side, a positionality as white, European and middle-class can help to get access to European institutions. Gaining access to border control authorities proved nevertheless challenging, especially in case of the consulates. Stephan was for instance only granted field access after promising to anonymise all information in such a way that it would neither allow to identify the country, in which consulate Z is located, nor the EU member state it represents. On the other side, the positionality as a white European researcher made it challenging to gain the trust of research participants from North African countries due to strong power asymmetries resulting from different positionalities in terms of class, race, nationality and access to mobility. Especially because migration candidates experience a high level of mistrust by authorities, building up trust to research participants from North Africa proved to be time-consuming and challenging. Miriam and Stephan also made different experiences and had different forms of access because of their gender. There was, for instance, only one woman among the 25 visa
} 
sections three and four are mostly based on Miriam's interviews with binational couples and consular staff in Morocco. However, both research projects' findings support all aspects of the arguments presented here. To clarify upon whose research we draw in particular passages of the text we always indicate our respective presence in the encounters under study with our first names.

\section{Studying the contested politics of marriage migration 'from below'}

Until the 1990s migration studies mostly neglected marriage migration, 'treating dependents as motivated by their ties to the [male] primary migrant, likely to be economically inactive, and therefore of little concern for research on migration which was predominantly focused on economic aspects' (Charsley 2012: 7). However, in the past two decades a growing body of literature has emerged which offers rich insights on marriage as a migration strategy and destination countries' attempts to reduce marriage migration through ever more restrictive requirements. These include the introduction of a minimum age (Muller Myrdahl 2010), minimum income-levels (Block and Bonjour 2013, Eggebø 2013), pre-departure integration requirements such as language tests (Bonjour and de Hart 2013, Gutekunst 2015) or, in Denmark, the requirement to prove that the couple's 'combined attachment' to Denmark is greater than that to any other country in the world (Wagner 2015). This literature offers important insights on how the regulation of marriage migration entails often invisibilized discriminations along lines of class, race and gender (Wray 2015, Block 2015, Gutekunst 2015, 2016) as well as tacit normative assumptions about family and gender relations (Pellander 2015) which play a crucial role in the production of collective (national) identities (Bonjour and de Hart 2013).

Nevertheless, we think that, taken together, the existing literature on marriage migration does not sufficiently account for important aspects of marriage migration and its government due to three biases. In the introduction we have already labelled these biases as an implementation gap bias, a control bias and a destination country bias. Before we discuss these in detail we want to stress, once more, that we understand these biases as tendencies in the body of literature on marriage migration as a whole. This means, first, that there always exist exceptions to any of these three tendencies, and secondly, that not all studies show all three biases identified by us. In the following we build on these works to highlight the need for and benefits of an analytical framework that transcends these.

applicants interviewed by Stephan since most female via applicants refused to meet a male European researcher after their appointment at the consulate in a nearby café. 
The first bias concerns the insufficient consideration of the gap between legal and policy frameworks and their actual implementation on the 'street-level'. Studies that rely on discourse and policy analysis clearly outnumber the small, albeit growing number of ethnographic studies that focus on the actual implementation of marriage migration related regulations (Infantino 2014, Gutekunst 2015, Pellander 2015, Maskens 2015, Scheel 2017, Carver 2013, Cole 2014).

What these studies demonstrate is that the ethnographic study of the government of marriage migration on the street-level of policy implementation is important for the following reasons. First, such an ethnographic approach can grasp the often significant divergence between official legal and administrative frameworks and their implementation by street-level bureaucrats on the ground. This is important because street-level bureaucrats in migration administrations often act as veritable policy makers as they bend, selectively ignore, adapt and in some cases even transgress legal norms (Lipsky 1980). In her study of consular practices concerning the issuance of certificates confirming the eligibility of a non-EU citizen to marry, Federica Infantino (2014) uncovers for instance several 'implementation tricks' by which consular staff side-line legally codified, fundamental rights to family life, thus turning the visa requirement into a mechanism to 'filter out' regular migrants perceived as 'unwanted'.

The ethnographic study of these practices permits furthermore to highlight how gender differences are enacted in and through bordering practices. The power category of gender is of particular relevance in context of marriage migration because nation-states seek to regulate marriage migration not only because of concerns over immigration, but in view of the biological and cultural reproduction of the nation (Yuval-Davis 2008 [1997]). Building on these insights, scholars of marriage migration show that normative ideas about love, relationships and related gender roles serve as important markers of a national identity and belonging (Block 2015, Cole 2014, Carver 2016, Bonjour and de Hart 2013). Based on the ethnographic study of respective assessments and decisions, others highlight that the regulation of marriage migration is less concerned with 'measuring the authenticity of the relationship' than with 'evaluating the desirability of the migrant partner' (Maskens 2015: 55) and that gender norms and stereotypes play a key role in these assessments (Leinonen and Pellander 2014, Alexander 2013, Pellander 2015). These studies demonstrate that the ethnographic study of implementation practices permits to unearth how gender norms and differentiations are (re)produced through bordering practices that seek to secure 'the '”genetic pool” of the nation' (Yuval-Davis 2008 [1997]: 22). Instead of assuming gender as a given category of power, the ethnographic study of implementation practices shows how 'doing gender' is intertwined with 'doing border' (Gutekunst 2016). 
Finally, an ethnographic methodology facilitates an intersectional approach that captures how the combination of multiple factors and discriminations along lines of age, class, gender, sexual orientation, race, and nationality shapes bureaucratic assessments and decisions in the regulation of marriage migration. Existing studies of implementation practices highlight the need for an 'intersectional perspective' (Leinonen and Pellander 2014: 1498). They also show that it is not just particular individual migrant bodies that raise suspicion and anxieties regarding 'the "proper” boundaries of the nation', but 'specific pairings of bodies' (d'Aoust 2017: 2). How particular constellations of binational couples are assessed by street-level bureaucrats and how the interplay of factors such as national pairings, age difference, sexual orientation etc. shapes the latter's decision-making is captured by an ethnographic analysis of binational couples' embodied encounters with authorities.

A second problematic tendency of the existing literature on marriage migration concerns its mostly one-dimensional preoccupation with ever more restrictive legislative frameworks and administrative hurdles. How binational couples navigate these restrictions is, in contrast, rarely considered (for exceptions see: Wagner 2015, Scheel 2017, Fernandez 2013, Leinonen and Pellander 2014, Cole 2014). Such 'control biased analyses' are problematic because they overrate the capacity of authorities to regulate (marriage) migration, resulting in the misrepresentation of border regimes as omnipotent control apparatuses (Scheel 2013a). Moreover, they tend to write out binational couples' struggles for visas, resident permits and family life, leading to de-politicised accounts of marriage migration 'management'. We believe that the ethnographic study of binational couples' 'border struggles' (Mezzadra and Neilson 2013) in their encounters with authorities offers a viable methodology for counterbalancing this bias..

This control bias is, thirdly, related to a destination country bias that pervades migration research in general (cf. Czaika and Haas 2014). With very few exceptions (Alexander 2013, Fernandez 2013), most studies are preoccupied with the analysis of marriage migration regulations in destination countries of the global North. The various (paper) requirements in the migrant spouse's country of citizenship are, if at all, only considered in footnotes or as a trifle towards the end of the analysis (e.g. Infantino 2014). From binational couples' viewpoint, these multiple entanglements in the citizenship and border regimes of two or more nation-state orders are, however, often not a minor matter as they impose sometimes conflicting demands on binational couples, as we show in the fourth section. This destination country bias has also been noted by Nadine Fernandez who observes in her study on Cuban marriage migration to Denmark that while ' $[\mathrm{t}]$ transnational marriages always involve two states [...], the non-western 
country involved is often overlooked' (2013: 271). To transcend this destination country bias we now outline an approach that follows binational couples' struggles within and against the citizenship and border regimes of two or more nation-states.

This approach is inspired by the autonomy of migration approach (AoM). As suggested by its name, the AoM proposes that migratory practices feature moments of uncontrollability and excess, that is moments of autonomy, in regards to any attempt to control or regulate them (Bojadžijev and Karakayali 2007). Yet, the AoM is not reducible to this provocative hypothesis. It offers a 'heuristic model' (Moulier Boutang 2007) for studying border regimes and migratory processes from the perspective of mobility. What is key to the AoM is that it makes migrants' practices and tactics of border crossing the starting point and focus in the analysis of border regimes and migratory processes. This calls for an ethnographic multi-sited methodology that follows migrants’ trajectories with a focus on their border struggles (Mezzadra 2011).

As a way to conduct such an 'ethnographic border regime analysis’ (Hess 2012), Scheel (2013b) suggests to make migrants' embodied encounters with the actors, means and methods of control the starting point of the analysis. It is in these embodied encounters that migrants' border struggles take place as two interacting, but antagonistic forces try to engross devices, technologies, regulations, third parties and so forth for their conflictive agendas (ibid, 285). These encounters are 'embodied' insofar as they always revolve around the bodies of particular mobile subjects though they might be mediated by devices (documents, digital data, files etc.) or third parties (lawyers, travel agents, private security firms etc.). The crucial point is that this body is always a human body that has been raced, classed, sexed and gendered as it is made the subject of various assessments and interrogations by street-level bureaucrats charged with migration control (ibid, 283-283). One advantage of studying embodied encounters is that this methodology captures the particularity of the situation under study without giving up on the possibility of drawing general conclusions about (marriage) migration and its government. For 'encounters between embodied subjects always hesitate between the domain of the particular the face-to-face of this encounter - and the general - the framing of the encounter by broader relationships of power and antagonism', as Sarah Ahmed (2000: 9) points out. A Moroccan man seeking to join his wife in Germany will, for instance, encounter a particular official at a particular consulate with a particular style of conducting an interview, but at the same time he will encounter the German border and citizenship regime as a whole.

What we would like to underscore is that the move towards the ethnographic study of embodied encounters is not reducible to a simple shift of the unit of analysis to the 'micro-level' of policy implementation. To focus analysis on the practices and interactions in binational 
couples' encounters with street-level bureaucrats rather means to embrace a constructivist ontology that understands borders and migration - as well as differentiations of power like class, race and gender - as realities that are both performative and performed. Put simply, neither borders nor marriage migration exist apart from the reiterative citation of bodily practices that enact them as tangible realities (cf. Scheel 2013b). Their performative nature is also why 'doing gender' is intertwined with 'doing border' (Gutekunst 2016). One of the concealed conventions that is reiterated through the citational practices of street-level bureaucrats (e.g. interrogating binational couples, verifying the authenticity of supporting documents, archiving files etc.) and those of binational couples (e.g. preparing for the interview, providing the requested paperwork, completing application forms) is the claimed prerogative of states to interfere - in highly classed, gendered and racialized ways - in the intimate lives of their citizens in order to secure the biological and cultural reproduction of the nation as a distinct community of belonging. To expose this crucial aspect of marriage migration and its government we propose an approach that follows binational couples' struggles within and against the intersecting border and citizenship regimes of their countries of origin and destination through a multi-sited ethnography that investigates their embodied encounters with all relevant authorities. This analytical framework permits to highlight particularly those aspects of marriage migration that have not been sufficiently considered by the existing literature, as we show in the three remaining sections.

\section{Informal hierarchies of desirability and the securitization of marriage migration from below} It was only during their fieldwork that Miriam and Stephan learned about the existence of a marriage-migration related phenomenon called 'bezness'. When Stephan asks about the high number of applications for family unification visa he observed in consulate $Z$, the head of the visa section (hereafter $M$ ) confirms that the share of family unification visa is continuously rising.. $\mathrm{M}$ adds: '[...] the biggest issue is young men who approach women in tourist resorts and persuade them to marry them. Then they stay with them until they receive their permanent residence permit. Often they then get divorced and marry a girl from their village. They call it "bezness".’ M advises Stephan to look up the term on the internet where one finds dozens of media reports and online portals that are characterised by a clear-cut distinction between female European victims and male foreign villains. In testimonies self-declared 'victims' of bezness 
depict local men as ‘false fairy-tale princes’ (Präkelt 2012) who ruthlessly exploit the feelings of European tourists in order to get a visa to Europe through a marriage. ${ }^{7}$

Miriam was confronted with the same narrative on bezness during her research in Morocco. The first question an employee of a consulate asks is: 'But you have already heard about bezness, haven't you?' He explains that his colleagues would frequently consult the webpage 1001 stories, the largest online-platform on bezness in Europe. ${ }^{8}$ They would use it as a source of information since they 'often have to deal with such cases. A large percentage are exactly these marriages.' In the following we show that the dominant public discourse on bezness with its gendered and racialized clear-cut distinction between female European victims and male foreign villains facilitates a securitization of marriage migration from below in consulates across North Africa..

During his second visit, Stephan sits with $\mathrm{M}$ in his back office where $\mathrm{M}$ processes the visa applications that have been received by frontline staff in the past few days. $M$ sits in front of his computer, a huge pile of files next to him. M takes a thick folder from the pile and starts to flip through the documents. A young man requests a visa to marry a woman from the country consulate $\mathrm{Z}$ is representing who is 20 years older than him. 'Look at this!' he says. 'She has already been married twice and she has two daughters, one of them is even two years older than the guy.' On the screen Stephan can read in the opinion section of the electronic file: 'note that the applicant does not speak proper French. He shows the typical profile of young men who engage in relationships with tourists in order to find a sponsor for a visa.' It has been entered by the staff who received the application at the front desk. M explains: 'The guy is from [...] in the South. There is nothing there. He has worked as a guide for excursions in the tourism sector. She says that's where they have met in November 2011. But there is no stamp in her passport.'

The application also contains a folder with photographs. The pictures show the couple having dinner, kissing in a swimming pool or him carrying her on his arms, another woman standing next to them. 'This must be the daughter. I don't understand her. How can she accept this?' There is another picture of the embracing couple kissing each other. 'Sometimes they even provide hot pictures. It can get quite disgusting. Who wants to see an old lady half-naked with

\footnotetext{
${ }^{7}$ This clear-cut victim-villain dichotomy is simplistic as it conceals the intertwinement of bezness with female sex tourism. Moreover, both phenomena are provoked and enabled by profound socioeconomic inequalities and a highly unequal access to mobility and life opportunities which is maintained by restrictive visa policies that render marriage to an EU-citizen the only legal migration option left for a large share of the local population (cf. Scheel 2017).

${ }^{8}$ The webpage is held in German and run by Evelyn Kern who has also published several books on bezness. Yet, these accounts are particularly problematic. Besides linking bezness to a particular culture and religion (namely Islam), they depict Muslim men in a stereotyping manner only as patriarchal, violent villains (cf. Präkelt 2012).
} 
a champagne bottle in her hand?' There is a series of pictures, showing the couple visiting the young man's parents. One picture portrays the woman, sitting on a sofa in the middle of his parents, all smiling. 'Look at this... the golden hen.' More pictures follow, showing the couple in poses and situations that are usually associated with romantic love: kissing at sunset or holding hands while walking over a beach. M puts the folder away. 'What does she want from him? It is obvious what he wants, but what does she want? He is 20 years younger; he can only be a sex toy for her. But why does she have to marry him, this is what I don't understand. Come here, enjoy yourself, but don't be stupid and start something serious...' M advises the central office for migration to reject the application. For formal reasons: the income of the woman is not sufficient to sustain her spouse and the claimed duration of their relationship cannot be verified due to the missing stamp in her passport.

M openly admits that he rejects most applications for family reunification visas by binational couples. Just like the head of another visa section (hereafter T) who tells Stephan in an interview that he regularly interviews local spouses applying for a family reunification visa on the basis of a catalogue of questions developed by the local migration administration in the country he is representing. The answers are recorded and sent back to the central migration administration in the capital where the final decision is taken. Just like M, T usually advises to reject the application. 'You have to consider that there is often a large age gap between the spouses and sometimes they do not even speak the same language. We then try to speak with them [European women seeking to marry a local young man].’

What these accounts highlight is that the hegemonic bezness discourse with its clear-cut distinction between European female victims and male non-European villains facilitates a securitisation of marriage migration 'from below' (Hammerstad 2012) that manifest itself on the street-level of policy implementation. Consular staff invoke the neat victim-villain distinction of this discourse to engage in informal practices of border control that go beyond their official competences. These informally institutionalised practices include the delay and initial denial of applications for family reunification visa. In this instance the securitization of migration is not driven by performative speech acts of political elites (Buzan, Waever, and de Wilde 1998) or routinized bureaucratic procedures of security professionals (Bigo 2002). It rather emerges as a diffuse and messy social process (Hammerstad 2012, Huysmans 2011) that also features lay people who disseminate threat narratives on migrants on webpages and in media-reports. These threat narratives - in the case of bezness accounts of calculating NorthAfrican men ruthlessly exploiting naïve European women - are then picked up by street-level 
bureaucrats in migration administrations where they inform decision-making about family application visa and are translated into informal border security practices.

The existence of such 'backstage administrative practices' (Infantino 2014: 28) has also been confirmed by other ethnographic studies on decision-making in European consulates. They include the initial denial of binational couples' applications for family reunification visa (Alpes and Spire 2014), the systematic delay of their applications (Spire 2009: 82-83) and attempts to persuade EU-citizens of their spouse's 'true' motivations for marriage (Kulk and Hart 2013, Maskens 2015). What all these practices share is that they complicate the family reunification procedure for binational couples, thus subjecting their relationships to severe tests that may provoke the split-up of the couple. Consular staff justify these practices, which go well beyond their competences, by mobilising the dominant bezness discourse in order to frame European women as victims deluded by their feelings who need to be protected from ruthless foreign men trying to exploit these by being protected from their irrational decision to marry them. In this way the construction of European women as naïve, vulnerable victims of 'foreign' migrant men translates into restrictive admission policies through a set of informal bureaucratic practices (Pellander 2015). Attempts to talk European women out of their marriage plans, the systematic delay and initial denial of their partners' visa requests are framed by consular staff as morally justified derogations from the law that serve the protection of European women. What the construction of a need for protection through the bezness discourse confirms is that the denial of agency to women in migration-related discourses permits to reconstruct the boundary between 'us' and 'them', a boundary that threatens to be destabilised by women who engage in binational personal relationships (Bonjour and de Hart 2013).

It is however a complex interplay of multiple factors - like the age difference between the couple and the class-background of the allegedly poor migrant spouse from the South - that shape - in conjunction with racialized and gendered stereotypes like that of the calculating migrant man and the naïve European women - the regulation of marriage migration in locally varying ways. The resulting need for a situated, intersectional analysis is also confirmed by $\mathrm{M}$ who openly admits that he approved most applications of family reunification visa for Thai women seeking to join their (often also much older) European husbands when he was stationed in Bangkok before being transferred to North Africa. ${ }^{9} \mathrm{M}$ justifies this differential treatment with a highly gendered stereotype of the reliable, caring Thai woman who would - in contrast

\footnotetext{
${ }^{9}$ Consular staff taking decisions on visa application are usually subject to a rotation scheme and are obliged to change their country of placement every two or three years. This rotation scheme serves as a precautionary measure against corruption.
} 
to young men from North Africa - 'stay with her husband and send money back home to their families.' In contrast to the situation in North Africa this would be a 'win-win situation'. He also added that in Bangkok it would have been more difficult for him to reject Thai women's applications for family reunification visa because their European husbands had - in contrast to many European women - a sufficient income to act as sponsors for their migrant partners. This confirms that racialized gender stereotypes and discriminations do not just pre-exist the moment of border inspection. They are rather enacted at sites of border control where they inform informal hierarchies of desirability that result in the differential treatment of people across intersecting lines of class, race, gender and so forth. This shows that 'doing border' is intertwined with the doing of class, race and gender. What is needed to account for these informal hierarchies of belonging, processes of securitization from below and informally institutionalised administrative practices is an ethnographic approach that investigates the government of marriage migration on the level of policy implementation in binational couples' encounters with street-level bureaucrats.

\section{Beyond the control bias: accounting for binational couples' border struggles}

Another important, but often neglected factor in the study of marriage migration is binational couples' capacity to negotiate and contest restrictive legislative frameworks and administrative practices. The importance of this factor is illustrated by the following account of R and Y's quest for a family reunification visa.

R, a 21-year-old Moroccan, met his German wife Y during her volunteering holidays in Casablanca. Miriam interviewed $\mathrm{R}$ after he had applied for a family reunification visa at the German consulate in Rabat. In the interview R reported to be surprised about consular staff's questions. Among others they had asked him whether he would have married a woman of Y's age if she had been Moroccan. While this hypothetical question confirms that migrant spouses are expected to adhere to the alleged norms of their 'indigenous culture' (Pellander 2015), R did not understand why it was regarded as a problem that his wife is older than him. The mere fact that the prophet Mohammed also had a wife, Khadija, who was twenty years older, is prove enough for $\mathrm{R}$ to confirm the legitimacy of such a relationship. The employee at the German consulate had also inquired how R and Y had met, how often they would see each other and what they had been doing during Y's holidays in Morocco. 'I told the whole story', said R, showing $\mathrm{X}$ a detailed timeline of $\mathrm{R}$ and $\mathrm{Y}$ 's relationship of the last two years that he had brought with him to the consulate. The timeline enlisted every flight to Morocco, every trip they had done together, every family event $\mathrm{Y}$ had attended. It had helped $\mathrm{R}$ to tell their story in such a 
detailed manner that it met the informal criteria of consular staff, ultimately prompting them to evaluate Y and R's relationship as 'genuine'.

After R had submitted his visa application Y received a letter from the local foreigners' office ['Ausländerbehörde'] in Germany. The letter asked Y to arrange an appointment because they had 'some questions'. Besides more documents, the letter asked Y to bring her passport and pictures documenting the time she had spent with $\mathrm{R}$ as well as a documentation of their Skype communication. After her interview at the foreigners' office, $\mathrm{Y}$ was desperate and angry: 'You feel like you are in the dock, although you haven't committed any crime. I think what is triggering this bad feeling is the suggestion that you as a woman are a little bit stupid ... that I do not realize that I get cheated.' $\mathrm{Y}$ had also brought the timeline of her relationship with $\mathrm{R}$ to the foreigners' office, together with pictures of their holidays. Yet, the employee at the foreigners' office was not satisfied. She criticised the missing date of the pictures' development. Moreover, Y had encountered difficulties with printing out the records of her Skype conversations with R. Instead Y had sent the foreigners' office a print-out of her Whatsapp conversations with R of the last two months. When Y left the foreigners' office, the employee informed her that further investigations were needed. Y and R felt powerless. They started to fear that they would never get a family reunification visa.

But three days later $\mathrm{R}$ was notified that he could pick up his visa at the consulate. Given the discouraging outcome of Y's appointment at the foreigners' office, both $\mathrm{R}$ and $\mathrm{Y}$ were surprised. When Miriam asked an employee at the consulate in Rabat about the case the employee looked up the notes of the foreigners' office in R's visa application. He reported that Y's 'performance' at the foreigners' office had been so convincing that it had nurtured, together with the fact that $Y$ pursues a successful professional career, the assumption that $Y$ 'knows what she is doing', as a comment by the foreigner's office in the file of R's visa application put it. Put differently, Y had successfully contested the gendered stereotype of the naïve European women that pervades the government of marriage migration in Europe (cf. Pellander 2015, Bonjour and de Hart 2013, Maskens 2015).

What this account of R and Y's eventually successful quest for a family reunification visa demonstrates is that binational couples are non-negligible actors in the study of marriage migration. To receive a family reunification visa, binational couples have to engage in a series of 'border struggles' (Mezzadra and Neilson 2013) with various street-level bureaucrats who subject binational couples' visa applications to a general suspicion. R und Y mobilise a range of tactics and practices to convince authorities of the 'authenticity' of their relationship These include the preparation of all requested documents and a detailed timeline of their relationship. 
Though there exists no legal requirement for binational couples to provide records of their Whatsapp or Skype communications, $\mathrm{R}$ and $\mathrm{Y}$ also comply with these invasive requests.

This performance of (over)compliance should not be reduced to docile submissiveness to authorities. Trying to satisfy the requests and anticipated decision-making criteria of consular staff and other street-level bureaucrats rather constitutes an important tactic in binational couples’ struggles for a family reunification visa against a bureaucratic apparatus whose very purpose is to restrict marriage migration to Europe. The reading of performed (over)compliance as a tactic that seeks to deprive street-level bureaucrats of any pretext to reject the application for a family reunification visa is particularly valid in a context in which marriage is treated 'as the "last loophole” in migration control policies' (Maskens 2015: 44). In their study of court cases on family reunification visa in Finland, Leinoen and Palleander (2014) describe for instance how male migrant spouses perform particular gender roles that conform to normative ideas and culturalised stereotypes about men in countries of origin or destination, depending on the perceived expectations of the court. There exist of course also other practices that might be regarded as more 'resistant'. Rikke Wagner (2015) interprets the practice of EU citizens to escape restrictive regulations in their country of citizenship by moving to another EU country as a form 'transnational civil disobedience'. Other examples include the usage of the parents' address as the binational couples' official home address to comply with housing requirements (Fernandez 2013). An analytical focus on these border struggles permits to politicise the 'management' of marriage migration as it allows to expose and critique how states interfere in their citizens' intimate and sexual lives to secure the biological and cultural reproduction of the 'nation' and to safeguard the boundaries of belonging of this racialized imagined community (cf. Yuval-Davis 2008 [1997]).

\section{Multiple Entanglements: Struggling within and against contradictory bureaucratic regimes}

Miriam met $\mathrm{N}$ at the Goethe Institute in Rabat where $\mathrm{N}$ attended a course to obtain a language certificate proving proficiency in German on level A1. The certificate is one of the paper requirements for a family reunification visa at the German consulate (Gutekunst 2015). N asked Miriam to accompany her to the family court where $\mathrm{N}$ had to verify the documents she and her German boyfriend had prepared for their wedding. Before applying for a family reunification visa, $\mathrm{N}$ did not only have to learn German, she also had to marry her boyfriend under Moroccan law. When Miriam and $\mathrm{N}$ entered the family court they quickly found a room where 'couples mixtes' ['mixed couples'] was written on the door. Inside, three women were sitting behind desks. All three were only responsible for the treatment of binational couples' dossiers. 
It was $\mathrm{N}$ and other binational couples who made Miriam aware of the importance of the Moroccan marriage system. Miriam's research focused on the procedures binational couples have to pass before they can live together in Germany. Due to the destination country bias in the literature on marriage migration, Miriam did however only learn during her fieldwork that, before entering a consulate of a Schengen member state, binational couples are already struggling with the legal system and bureaucratic jungle of another nation-state. These entanglements of binational couples in the laws, discourses and administrative systems of the border and citizenship regimes of the non-European spouse's country of citizenship can be quite substantial, as the example of Morocco demonstrates.

As in other parts of the world, religion plays an important role in Morocco in the context of marriages. In general, Islam is defined as the religion of the state in the Moroccan constitution (Khallouk 2008: 14). The intent to avoid any behaviour that is not halal, i.e. that is not allowed according to Islamic law, extends to all spheres of life and is inscribed in Moroccan legislation. Following article 39/4 of the Moudawana, the Moroccan family law, marriage between a Muslim woman and a non-Muslim man and, in some instances, ${ }^{10}$ also marriage between a Muslim man and a non-Muslim woman, are prohibited (Ministère de la Justice 2004: 25). This examples demonstrates that legal requirements and administrative procedures concerning the 'exit dimension' of marriage migration in the non-European spouse's country of citizenship are also constitutive of differentiations and discriminations along intersecting categorisations of power, in this instance gender and religious background. Consequently, male non-Muslim spouses (like N’s partner) have to convert to Islam before they are allowed to marry a Moroccan woman. This conversion involves an examination of the convert's religious conviction who will be examined by a judge at the family court where couples have to apply for the permission to marry. After the procedure $\mathrm{N}$ told Miriam that the judge had asked her boyfriend to name the five pillars of Islam and how often he was praying.

Moreover, all binational couples seeking to marry in Morocco have to pass another assessment by state officials called enquête de police [police inquiry]. This assessment concerns the interdiction of sexual intercourse before marriage. Following article 490 of Moroccan criminal law 'all persons of different sexes who are not married and have sexual relationships together are punished with imprisonment between one month and one year' (Ministère de la

\footnotetext{
10 This difference results from the differential treatment of Muslim man and women in Moroccan family law: whereas Muslim women can only marry Muslim men, the latter can also marry a non-Muslim woman if the latter belongs to one of the religions that comprise a 'holy book' like the Bible or the Thora. The most important religions that are recognized as 'book religions' by Islamic law (apart of Islam) are Christianity and Judaism. In practical terms, a Muslim man can thus marry a non-Muslim woman in Morocco if she is Christian or Jewish.
} 
Justice 2015, author's translation). Normally Moroccan authorities do not ask for certificates proving the partners' virginity, but binational couples who marry under Moroccan law have to provide an authorisation by the 'prosecutor of the King'. To obtain this authorisation binational couples have to pass the police inquiry in which they have to answer sometimes highly indiscrete questions about their relationships: How they have met, how often they see each other, and in what kind of sexual activities they engage. $\mathrm{N}$ already knew from another binational couple that the police would ask her if she and her partner already had sexual intercourse. She told Miriam: 'We will say no. If we tell the truth we will be in trouble.' Other couples interviewed by Miriam also knew from blogs or other couples that they had to negate this question. Otherwise the couple risks imprisonment or the denial of authorisation for marriage. ${ }^{11}$ One Moroccan woman interviewed by Miriam had been asked by the police to provide a medical certificate confirming her virginity. This example illustrates how deeply the Moroccan state intervenes in the personal affairs and intimate lives of binational couples.

If a binational couple has obtained permission to marry from the prosecutor of the king, the last bureaucratic hurdle consists of visiting the adoul who holds the position of a notary under Islamic law. The adoul is responsible for the issuance of marriage certificates. Spouses not in command of Arabic will find it difficult to understand the marriage certificate which contains legal regulations specific to Moroccan family law. A woman from Germany told Miriam that she had to insist on having the document translated. She also insisted on adding several clauses, for example, that she would be allowed to travel alone with their children and that she could decide where her children live.

Once married under Moroccan law, binational couples can start to apply for a family reunification visa of a Schengen member state. At the consulate they face more bureaucratic hurdles, further investigations about their relationship and more street-level bureaucrats implementing legal frameworks and administrative procedures of another nation-state order. The first step of navigating this second bureaucratic obstacle course is to translate the marriage certificate from Arabic into the official language of the member state where the binational couple wants to apply for a family reunification visa. This second bureaucratic obstacle course constitutes, however, the analytical starting point of most studies on marriage migration due to the destination country bias of the existing literature. The investigation of marriage migration regulations from the perspective of binational couples shows, however, that it is important to account for what we call binational couples' multiple entanglements in legal frameworks, policy

\footnotetext{
${ }^{11}$ See the post 'Mariage au Maroc’ auf dem Blog Vichaa: http://vichaaa.joueb.com/ (20.12.2016).
} 
discourses and administrative jungles of the border and citizenship regimes of two or more nation-states and/or supranational orders. ${ }^{12}$

These multiple entanglements are far from surprising if one considers that any migration entails a process of immigration and a process of emigration and that some form of exit control and 'moral gatekeeping' (Wray 2006) exist in most countries, especially when it comes to crossborder marriage and long-term emigration. Until January 2013 Cuban citizens needed for instance an exit visa to leave the country and they still require a foreign residency permit to retain their residency, inheritance and property rights, which they can, in practice, only obtain by marrying a foreign citizen (Fernandez 2013). What the examples of Cuba and Morocco suggest is that scholars of marriage migration conduct a semi-finished analysis if they only consider how the entry-regimes of (mostly European) destination countries affect the migration process of bi-national couples. The following conclusion of Aristide Zolberg thus also holds true for the study of marriage migration: 'Given the considerable variation in exit policies that can be observed [...] and their interactivity with immigration policies elsewhere, it is evident that a comprehensive theory pertaining to the role of states in regulating international migration must cover the exit side as well' (1999: 82).

In our view it is important to account for binational couples' multiple entanglements in two or more overlapping border and citizenship regimes for the following three reasons. First, binational couples have already learned that they have to perform their relationship in a way that suits the desired narratives and informal decision-making criteria of state officials by the time they encounter the European border regime. It is important to consider this 'learning effect', especially if one acknowledges, secondly, that the desired narratives and decisionmaking criteria can differ substantially from one border and citizenship regime to the next. For instance, a shared bed or holidays spent together are considered as evidence for a 'genuine' relationship in consulates of Schengen member states. This is why binational couples sometimes add 'hot pictures' to their visa applications. Moroccan authorities would interpret such pictures, in contrast, as indices of a breach of article 490, deny authorisation of marriage and maybe even initiate criminal investigations. Due to their multiple entanglements in the border and citizenship regimes of two or more nation-state orders binational couples are therefore sometimes be compelled to engage in 'forced fraud' (Garcia 1997). To satisfy

\footnotetext{
12 The entanglement of binational couples in border and citizenship regimes of more than two nation-states and/or supranational orders like the EU is not a rare occurrence. Such constellations rather seem to multiply as binational couples increasingly try to escape restrictive marriage migration regulations in their country of citizenship by moving to another country (Wagner 2015).
} 
conflicting demands binational couples may have to develop various narratives of their relationship and also fabricate suitable 'evidence’ supporting these narratives.

Finally, binational couples' multiple entanglements in the border and citizenship regimes of two or more nation-state orders defies any easy generalisations about marriage migration and its government. What kind of legal frameworks, public discourses and administrative particularities are involved and how these play themselves out depends not only on the constellation of the binational couple in terms of citizenship and destination country, but also on the positionality of both partners in terms of class, race, age, gender and sexual orientation. What is needed to account for binational couples' multiple entanglements is thus a multi-sited ethnography of binational couples' embodied encounters and border struggles with all marriage migration relevant authorities in countries of citizenship and destination.

\section{Conclusion}

In this article we have proposed an analytical framework that permits to transcend three biases and related limitations that we have identified in the existing literature on marriage migration. This approach follows binational couples' trajectories through the entire marriage migration process by ethnographically studying the embodied encounters of both partners with all relevant authorities in both countries of citizenship and destination. Inspired by the AoM , this approach investigates these encounters from binational couples' perspective with a particular focus on their border struggles. This implies to take sides in the contested politics of marriage migration in political and epistemological terms by making binational couples' practices and struggles the starting point and focus of the analysis. While participant observation is the preferred method for studying embodied encounters, scholars may also treat the protagonists of these encounters (binational couples and street-level bureaucrats alike) as chroniclers of their practices and encounters. Crucially, the adoption of binational couples' perspective permits scholars to bring out the irreducibly political quality of their struggles within and against the border and citizenship regimes of two or more nation-state orders. These struggles are inherently political because they expose how nation-states try to regulate and interfere - in highly gendered and racialized ways - in the intimate lives and personal affairs of their citizens and how binational couples render this claimed prerogative as an issue of contestation and dissent.

\section{References}


Ahmed, Sara. 2000. Strange Encounters: Embodied Others in Post-Coloniality. London/ New York: Routledge.

Alexander, Claire. 2013. "Marriage, Migration, Multiculturalism: Gendering 'The Bengal Diaspora'." Journal of Ethnic and Migration Studies 39 (3):333-351.

Alpes, Maybritt Jill, and Alexis Spire. 2014. "Dealing with Law in Migration Control: The Powers of Street-level-Bureaucrats at French Consulates." Social \& Legal Studies 23 (2):261-274.

Bigo, Didier. 2002. "Security and Immigration: Toward a Critique of the Governmentality of Unease." Alternatives: Global, Local, Political 27 (1, special issue):63-92.

Block, Laura. 2015. "Regulating Membership: Explaining Restriction and Stratification of Family Migration in Europe." Journal of Family Issues 36 (11):1433-1452.

Block, Laura, and Saskia Bonjour. 2013. "Fortress Europe or Europe of Rights? The Europeanisation of Family Migration Policies in France, Germany and the Netherlands." European Journal of Migration and Law 15 (2):203-224.

Bojadžijev, Manuela, and Serhat Karakayali. 2007. "Autonomie der Migration. 10 Thesen zu einer Methode." In Turbulente Ränder. Neue Perspektiven auf Migration an den Grenzen Europas, edited by Transit Migration, 203-210. Bielefeld: transcript.

Bonjour, Saskia, and Betty de Hart. 2013. "A Proper Wife, a Proper Marriage: Constructions of "Us" and "Them" in Dutch Family Migration Policy." European Journal of Women's Studies 20 (1):61-76.

Butler, Judith. 1993. Bodies that Matter. On the Discursive Limits of "Sex". London: Routledge.

Buzan, Barry, Ole Waever, and Jaap de Wilde. 1998. Security: A New Framework for Analysis. Boulder Lynne Rienner.

Carver, Natasha. 2013. "Displaying Genuineness: Cultural Translation in the Drafting of Marriage Narratives for Immigration Applications and Appeals." Families, Relationships and Societies 3 (2):271-286.

Carver, Natasha. 2016. "'For Her Protection and Benefit’: The Regulation of Marriage-related Migration to the UK." Ethnic and Racial Studies 39 (15):2758-2776.

Charsley, Katherine. 2012. "Transnational Marriage." In Transnational Marriage: New Perspectives from Europe and Beyond, edited by Katherine Charsley, 3-22. London and New York: Routledge.

Cole, Jennifer. 2014. "Working Mis/Understandings: The Tangled Relationship between Kinship, Franco-Malagasy Binational Marriages, and the French State." Cultural Anthropology 29 (3):527-551.

Constable, Nicole 2004. Cross-Border Marriages. Gender and Mobility in Transnational Asia. Philadelphia: University of Pennsylvania Press.

Czaika, Mathias, and Hein de Haas. 2014. "The Globalization of Migration: Has the World Become More Migratory?" International Migration Review 48 (2):283-323. 
D'Aoust, Anne-Marie. 2013. "In the Name of Love: Marriage Migration, Governmentality and Technologies of Love." International Political Sociology 7 (3):258-274.

d'Aoust, Anne-Marie. 2017. "A Moral Economy of Suspicion: Love and Marriage Migration Management Practices in the United Kingdom." Environment and Planning D: Society and Space (Online First).

Eggebø, Helga. 2013. "A Real Marriage? Applying for Marriage Migration to Norway." Journal of Ethnic and Migration Studies 39 (5):773-789.

Fernandez, Nadine. 2013. "Moral Boundaries and National Borders: Cuban Marriage Migration to Denmark." Identities: Global Studies in Culture and Power 20 (3):270-287.

Garcia, Sandrine. 1997. "La fraude forcée." Actes de la Recherche en Science Sociales (118):81-91.

Gutekunst, Miriam. 2015. "Language as a New Instrument of Border Control: the Regulation of Marriage Migration from Morocco to Germany." The Journal of North African Studies 20 (4):540-552.

Gutekunst, Miriam. 2016. "Doing Gender und das Regieren der Migration durch Heirat. Eine ethnographische Analyse der wechselseitigen Konstitution von Geschlecht und Grenze." Feministische Studien 34 (2):226-241.

Hammerstad, Anne. 2012. "Securitisation from below: The Relationship between Immigration and Foreign Policy in South Africa's Approach to the Zimbabwe Crisis." Conflict, Security and Development 12 (1):1-30.

Hess, Sabine. 2012. "De-Naturalising Transit Migration. Theory and Methods of an Ethnographic Regime Analysis." Population, Space and Place 18 (4):428-440.

Huysmans, Jef. 2011. "What's in an Act? On Security Speech Acts and Little Security Nothings." Security Dialogue 42 (4-5):371-383.

Infantino, Federica. 2014. "Bordering 'Fake' Marriages? The Everyday Practices of Control at the Consulates of Belgium, France and Italy in Casablanca." Ethnografia E Ricerca Qualitativa 2014/1:27-49.

Khallouk, Mohammed 2008. Islamischer Fundamentalismus vor den Toren Europas: Marokko zwischen Rückfall ins Mittelalter und westlicher Modernität. Berlin: Springer VS.

Kulk, Frisco, and Betty De Hart. 2013. "Mixed Couples and Islamic Family Law in Egypt: Legal Consciousness in Transnational Social Space " Oñati Socio-Legal Series 3 (6):1057-1069.

Leinonen, Johanna, and Saara Pellander. 2014. "Court Decisions over Marriage Migration in Finland: A Problem with Transnational Family Ties." Joournal of Ethnic and Migration Studies 40 (9):1488-1506.

Lipsky, Michael. 1980. Street-Level Bureaucracy: Dilemmas of the Individual in Public Services. New York: Russell Sage Foundation. 
Marcus, George. 1995. "Ethnography in/of the World-System: The Emergence of Multi-Sited Geography." Annual Review of Anthropology 24 (1):95-117.

Maskens, Maïté. 2015. "Bordering Intimacy: The Fight against Marriages of Convenience in Brussels." The Cambridge Journal of Anthropology 33 (2):42-58.

Mezzadra, Sandro. 2011. "The Gaze of Autonomy: Capitalism, Migration and Social Struggles." In The Contested Politics of Mobility Borderzones and Irregularity edited by Vicky Squire, 121-142. London: Routledge.

Mezzadra, Sandro, and Brett Neilson. 2013. Border as Method, Or, the Multiplication of Labor. Durham: Duke University Press.

Ministère de la Justice. 2004. Code de la Famille. La Moudawana. http://www.consulatdumaroc.ca/forms/codefamillefr.pdf (20.12.2016).

Ministère de la $2015 . \quad$ Justice. Code Pénal. http://adala.justice.gov.ma/production/legislation/fr/penal/Code\%20Penal.htm, 20.12.2016.

Moulier Boutang, Yann. 2007. "Europa, Autonomie der Migration, Biopolitik." In Empire und die biopolitische Wende. Die Internationale Diskussion im Anschluss an Negri und Hardt, edited by Marianne Pieper, Thomas Atzert, Serhat Karakayali and Vassilis Tsianos, 169-178. Frankfurt am Main: Campus.

Muller Myrdahl, Eileen. 2010. "Legislating Love: Norwegian Family Reunification Law as a Racial Project." Social \& Cultural Geography 11 (2):103-116.

Pellander, Saara. 2015. "“An Acceptable Marriage”: Marriage Migration and Moral Gatekeeping in Finland." Journal of Family Issues 36 (11):1472-1489.

Piper, Nicola, and Mina Roces. 2003. "Introduction: Marriage and Migration in an Age of Globalization." In Wife or Worker? Asian Women and Migration, edited by Nicola Piper and Mina Roces, 1-22. Lanham: Rowman \& Littlefield Publishers.

Präkelt, Kathalina. 2012. "Bezness-Prävention im Internet: Die Rache der Strandprinzessinnen." taz, 29.02.2012.

Scheel, Stephan. 2013a. "Autonomy of Migration Despite Its Securitisation? Facing the Terms and Conditions of Biometric Rebordering." Millennium - Journal of International Studies 41 (3):575-600.

Scheel, Stephan. 2013b. "Studying Embodied Encounters: Autonomy of Migration Beyond its Romanticization." Postcolonial Studies 16 (3):279-288.

Scheel, Stephan. 2017. "Appropriating Mobility and Bordering Europe through Romantic Love: Uncovering the Intertwinement of Border Regimes and Migratory Practices." Migration Studies 5 (3):389-408.

Spire, Alexis. 2009. Accueillir ou reconduire: Enquête sur les guichets de l'immigration. Paris: Raisons d'Agir Éditions. 
Wagner, Rikke. 2015. "Transnational Civil Dis/Obedience' in the Danish Family Unification Dispute." European Political Science Review 7 (1):43-62.

Williams, Lucy. 2012. "Transnational Marriage and Marriage Migration." In Transnational Marriage: New Perspectives from Europe and Beyond, edited by Katherine Charsley, 23-37. London and New York: Routledge.

Wray, Helena. 2006. "Ideal Husband - Marriages of Convenience, Moral Gate-keeping and Immigration to the UK." European Journal of Migration and Law 8 (3-4):303-320.

Wray, Helena. 2015. "“'A Thing Apart”: Controlling Male Family Migration to the United Kingdom." Men and Masculinities 18 (4):424-447.

Yuval-Davis, Nira. 2008 [1997]. Gender and Nation. Los Angeles \& London: Sage.

Zolberg, Aristide. 1999. "Matters of the State: Theorizing Immigration Policy." In The Handbook of International Migration: The American Experience, edited by Charles Hirschman, Philip Kasinitz and Josh DeWind, 71-93. New York: Russell Sage Foundation. 


\section{DuEPublico}

Duisburg-Essen Publications online
DE US ISEN R G

offen im Denken

Ub $\mid \begin{aligned} & \text { universitäts } \\ & \text { bibliothek }\end{aligned}$

This text is made available via DuEPublico, the institutional repository of the University of Duisburg-Essen. This version may eventually differ from another version distributed by a commercial publisher.

DOI: $\quad 10.1080 / 0966369 X .2018 .1489375$

URN: urn:nbn:de:hbz:464-20210527-114539-7

This is the author accepted pre-proof version of an article published by Taylor \& Francis on 25 Jan 2019 in: Gender, Place and Culture (2019) 26:6, 847-867.

The final version is available online at: https://doi.org/10.1080/0966369X.2018.1489375

All rights reserved. 